\title{
Australia's strategic options in the US-China relationship
}

\author{
Allan Behm
}

As with most papers written by former public servants, this one begins with two disclaimers. First, the views expressed here are those of the author alone, and in no way intended to reflect the policies or the views of the Australian Department of Defence. Second, this is not an academic contribution. Rather, it is a practitioner's view. It details ideas that are the result of nearly two decades devoted to the implementation and practice of strategic policy. It does not pretend to comment on the theories of academic writers on the subject of US-China relations. Hence it does not cite authorities for the opinions offered, and reference to other commentators does not assume their endorsement.

The ideas advanced in this chapter are a distillation from personal participation in high-level discussions conducted in China, the United States and Australia. The author was a member of Prime Minister Malcolm Fraser's delegation that visited Beijing for discussions with Premier Zhao Ze-yang in 1982, and accompanied Defence Minister John Moore on his visit to China in 1999, when he met Premier Zhu Rong-ji. In the intervening years, the author participated in official talks between the Australian Department of Defence and the People's Liberation Army (PLA), and was a member of several 'one-and-a-half-track' delegations. The author was also the first senior Defence official to hold discussions with the PLA following the PLA's suppression of the Tienanmen Square demonstrations in 1989.

The author also participated in and led official talks and discussions with US counterparts over many years, and has discussed US-China relations with senior members of the Reagan, Bush and Clinton administrations, as well as leading US academics and commentators. The author also visited numerous US universities and research institutions, and participated in various seminars and discussions on strategic issues affecting the US-China relationship. But, in the end, impressions are no more than that: they are offered as a contribution to the broader understanding of the strategic complexities attaching to the China-US relationship.

And, finally, a word on strategy: in this chapter, the term is used in the specific sense of high policy surrounding the use of armed force. As Clausewitz (1984, 
177) says, 'strategy is the use of engagement [i.e. armed force] for the purpose of the war'. In other words, 'strategy' deals with the grounds upon which the government of China or the United States might consider the deployment and employment of its military power against the other. This is not, of course, an insignificant matter. Consideration of the use of armed force, particularly against a major power, assumes that every diplomatic avenue has been tried, and exhausted. Hence, armed conflict is an unlikely outcome in the proper management of the bilateral political relationship between China and the US. What this chapter attempts is to examine a fundamental antinomy that might lie at the centre of a future major deterioration in the strategic relationship between these two great powers.

\section{The basic dilemma}

At the Australian American Leadership Dialogue held in Sydney in August 1999, Richard Armitage proffered some telling advice on the choices Australia would have to make should the United States and China resort to armed conflict over Taiwan. Armitage said that the United States would expect Australia to provide meaningful military support to the United States in order to carry out 'dirty, hard and dangerous' work. He noted that not only were Australia's interests directly engaged in the outcome of such a confrontation, but that its alliance with the US would indicate such support. Armitage was, at the time, an influential and wellplaced member of the Republican team-in-waiting. Currently, Armitage is the Deputy Secretary for State in the Bush Administration. His ideas have currency.

Armitage may have been intending to be helpful to Australian policy makers. He was certainly right in identifying the dilemma facing them: how would Australia seek to balance the economic advantages deriving from its relationship with China with the strategic benefits it derives from its relationship with the United States? At the time, Canberra policy advisers ran for cover, concerned as much with avoiding admitting an unpleasant truth to China as with facing up to a US expectation deriving from alliance arrangements. A day or two later, Alan Jones, a presenter at radio station 2UE in Sydney, put the issue to Alexander Downer, the Minister for Foreign Affairs. Downer commented:

No government is going to get into a position of speculating on a whole series of completely hypothetical scenarios...In foreign policy, much as it is fun to discuss these scenarios, you can't publicly canvass those sorts of things...We can only urge China and Taiwan to work together (Downer 1999).

This is, of course, a textbook Foreign Minister's reply. Why court the danger of making a choice between the United States and China when the problem can be reformulated as a China-Taiwan issue. And diplomacy is, rightly, about steering between hard issues in order to maximize the benefits of even-handedness. 
But strategy must deal with the 'what ifs'. What if China and Taiwan cannot work together? What if Taiwan were to provoke a Chinese military retaliation for an excess of independence? What if China were to sanction a more assertive and strident Taiwan by pre-emptive military intervention? What if centrifugal tendencies within China itself were to lead Beijing to assert its authority once and for all over Taipei? What if China and the US were to confront each other over an altogether different issue? Could Australia reasonably remain neutral with respect to either the protagonists or the outcome? This chapter suggests that, while any Australian government would have a range of options, neither support for China nor neutrality would provide a realistic strategic response for Australia. An Australian government would, of course, seek to maximize benefits to Australia that might emerge from the resolution of a China-US confrontation. But, in the sorts of time frames that are credible for force planners (roughly the life span of major current and planned weapons systems), Australia's strategic interests align with those of the US.

\section{Discontinuity}

In On War, Clausewitz reminds us 'war is not a mere act of policy but a true political instrument, a continuation of political activity by other means' (Clausewitz 1984, 87). And, as with all political activities, it is intrinsically discontinuous. The elements that combine to create the strategic environment at any one time are not univocal, and they do not act in concert and harmony. Indeed, they are fundamentally disparate, so that the strategic environment is the expression of competition and contradiction between needs, interests and expectations, the resolution of which may invoke the use of armed force.

Because policy is the product of human decision-making it, too, is discontinuous. It changes over time, sometimes in an evolutionary way, often in a markedly disruptive and destructive way. For policy is the distillation of complex social and cultural factors that find their expression in goals and objectives that may be only partially articulated - if, indeed, they are articulated at all. The deep cultural drivers of policy are the result of the historical experiences of peoples and nations and, as such, are generally implicit in the development of approaches to policy over time. The deep cultural drivers of policy derive from the basic assumptions-rarely given any formal expression-on which societies base their ability to maintain some sort of equilibrium between competing interest groups. These assumptions define the fundamental decision-making paradigm on which societies, and particularly their leaders, base their pursuit of important outcomes and benefits.

It is impossible, of course, to identify a single expression of the decisionmaking paradigm on which national leaderships base their policies. It is a hydraheaded monster, the very stuff of political commentary. And if the discontinuities that underpin any national decision-making paradigm are incapable of any single expression, then the discontinuities that inform the strategic decision-making 
paradigm are even more difficult to express. It is for that reason that Alexander Downer shied away from Alan Jones's question, and sheltered behind 'a whole series of completely hypothetical scenarios'. Any political decision-maker worth his or her salt would have done the same.

Now, if it is difficult to establish a clear articulation of the discontinuities intrinsic to any individual strategic decision-making paradigm, it is probably impossible to offer a comprehensive description of the forces that define the strategic environment at any given time-especially one as fraught as that existing between China and the United States. But it seems to this writer, at least, that the attempt to analyse the fundamental nature of the strategic discontinuity between the strategic paradigms of China and the US might go some way to clarifying the basic factors that would determine the options of third parties, such as Australia.

\section{The Chinese strategic paradigm}

China is meticulous in its signal giving. So it is probably no accident that the item usually offered in the official exchange of gifts that marks high-level meetings between China's Defence Minister, General Chi Haotian, and his counterparts is a splendidly engraved copy of Sun Tze's The Art of War. Notwithstanding the many essays on strategy and warfare written in China over the centuries, The Art of War stands as the authoritative expression of the Chinese philosophy of armed conflict. Written in the sixth century $\mathrm{BC}$, it is a masterpiece of strategic analysis, distilling centuries of Chinese martial experience. It reflects as much on insurrections, clan wars, and invasions by external forces as it does on the place of armed power in the exercise of statecraft.

If one studies the excellent 1910 translation and notes prepared by Lionel Giles (rather out of date, but illuminating for its critica), one quickly notes the basic 'push-pull' nature of Sun Tze's analysis of warfare, whether the subject for consideration is the financing of war, its prosecution, the raising of troops, and so forth. In the first chapter 'Laying Plans', for instance, Sun Tze says, '[war] is a matter of life or death, a road either to safety or to ruin' $(1910,1,2)$. He goes on to say:

All warfare is based on deception.

Hence, when able to attack, we must seem unable; when using our forces, we must seem inactive; when we are near, we must make the enemy believe we are far away; when far away, we must make him believe we are near $(1910,1.18-19)$.

He concludes the chapter by noting:

Thus do many calculations lead to victory, and few calculations to defeat: how much more no calculation at all! It is by attention to this point that I can foresee who is likely to win or lose $(1910,1.26)$.

The concept is that of the 'zero-sum game'. 
As one proceeds through the 13 short chapters of The Art of War, one is constantly aware of the measured balance struck between positives and negatives: between victory and defeat, success and failure, winning and losing. This is not simply due to the aphoristic style of Sun Tze's writing. Rather, the dialectic is fundamental to Sun Tze's philosophy of war. But he does not suggest that total defeat and annihilation is the necessary result of armed conflict. In his analysis of 'Attack by Stratagem', he notes:

In the practical art of war, the best thing of all is to take the enemy's country whole and intact; to shatter and destroy it is not so good. So, too, it is better to recapture an army entire than to destroy it, to capture a regiment, a detachment or a company entire than to destroy them.

Hence to fight and conquer in all your battles is not supreme excellence; supreme excellence consists in breaking the enemy's resistance without fighting $(1910,3.1-2)$,

For Sun Tze, victory is not destruction, but rather the subjugation of the enemy.

Sun Tze's basic metaphors for war derive from nature: the coming and going of the seasons; water seeking its own level; the potential energy of rocks in high places, to be actualized in the rush of battle. It is the world of classical physics, where 'to every force there is an equal and opposite reaction force', as Newton said. He is also an advocate of the indirect strategy.

Thus one who is skilful at keeping the enemy on the move maintains deceitful appearances, according to which the enemy will act. He sacrifices something, that the enemy may snatch at it $(1910,5.19)$.

In all of this, Sun Tze's basic construct is that the defence of the nation and the promotion of its interests are achievable only if a competitor's interests are correspondingly reduced. Again, it is a 'zero-sum game' construct.

\section{Sun Tze revisited-Mao Tse-tung}

Of course, much has happened in the two and a half thousand years since Sun Tze reflected on the nature of war to shape further China's basic strategic paradigm. Yet, in the main, China's historical experience of armed conflict has tended to confirm Sun Tze's thesis rather than to change it. Perhaps the most forceful strategist of the twentieth century, Mao Tse-tung, had this to say in 1936: 'War is the highest form of struggle for resolving contradictions, when they have developed to a certain stage, between classes, nations, states, or political groups, and it has existed ever since the emergence of private property and of classes' (Mao 1936, 180).

Mao Tse-tung was, arguably, history's greatest proponent of armed struggle as an essential component of political revolution and social reform. Yet his basic conceptual model reflected the 'action-reaction' paradigm so characteristic of 
Chinese strategic thinking. He could imagine a world without war. Yet war was itself essential for such a world to come to pass. In the same essay in 1936, he said:

\begin{abstract}
War, this monster of mutual slaughter among men, will be finally eliminated by the progress of human society, and in the not too distant future too. But there is only one way to eliminate it and that is to oppose war with war, to oppose counter-revolutionary war with revolutionary war, to oppose national counter-revolutionary war with national revolutionary war, and to oppose counter-revolutionary class war with revolutionary class war... When human society advances to the point where classes and states are eliminated, there will be no more wars, counter-revolutionary or revolutionary, unjust or just; that will be the era of perpetual peace for mankind. Our study of the laws of revolutionary war springs from the desire to eliminate all wars; herein lies the distinction between us Communists and all the exploiting classes (Mao $1936,182-3)$.
\end{abstract}

If one considers the circumstances in which Mao Tse-tung theorized in this way (the continuing revolutionary war against the nationalist forces under Chiang-Kaichek and the war with Japan), the conception is all the more astonishing.

The same dogged zero-sum dualism underpinned Mao's entire approach to China's place in the world balance. Speaking to the preparatory committee of the New Political Consultative Conference in June 1949, he said:

Just because we have won victory, we must never relax our vigilance against the frenzied plots for revenge by the imperialists and their running dogs. Whoever relaxes vigilance will disarm himself politically and land himself in a passive position (Mao 1949, 407).

This same paradigm informed Mao's approach to the Korean War and, most importantly, offers a fundamental insight into his thinking on the antithetical nature of the strategic relationship between China and the United States.

In his speech to the fourth session of the First National Committee of the Chinese People's Political Consultative Conference in February 1953, he said:

So long as US imperialism refuses to give up its arrogant and unreasonable demands and its scheme to extend aggression, the only course for the Chinese people is to remain determined to go on fighting side by side with the Korean people. Not that we are warlike. We are willing to stop the war at once and leave the remaining questions for later settlement. But US imperialism is not willing to do so. All right then, let the fighting go on. However many years US imperialism wants to fight, we are ready to fight up to the moment within it is willing to stop, right up to the moment of complete victory for the Chinese and Korean peoples'.

The same apocalyptic vision characterized his attitudes towards the US throughout his long reign as Chairman. In November 1964, he exhorted the world to defeat the United States. 
People of the world, unite and defeat the US aggressors and all their running dogs! People of the world, be courageous, dare to fight, defy difficulties and advance wave upon wave. The whole world will belong to the people. Monsters of all kinds shall be destroyed (Mao 1964, 14).

This chapter is not intended as an exegesis of Chinese strategic texts over the centuries. Rather, it is to suggest that there is a basic paradigm that underpins China's approach to strategy and to war. This zero-sum game approachespecially in the face of China's evident weakness as a strategic competitor of the US--may also explain what Harry Harding (1986) has described as China's policy of 'passive aggression'.

While no Chinese government will embark on a suicidal confrontation with the US, the zero-sum game basis of continuing Chinese strategic policy perpetuates the risks of misunderstanding and miscalculation. Moreover, it may lend a certain inevitability to serious confrontation between China and the US. As reported by the $\mathrm{BBC}$ on 6 January 2000, China's Defence Minister, General Chi Hao-tian is quoted as saying:

Seen from the changes in the world situation and the United States' hegemonic strategy for creating monopolarity, war is inevitable. We cannot avoid it. The issue is that the Chinese armed forces must control the initiative in this war. We must make sure that we will win in this local hightech war against aggression and interference; win this modern high-tech war that [the] military bloc, headed by US hegemonists, may launch to interfere in our affairs militarily; and win this war ignited by aggressor countries' sudden offensive against China. We must be prepared to fight for one year, two years, three years, or even longer (Chi 1999).

This is a sobering thought, even if it is driven by the dialectical inevitabilities of the Chinese strategic calculus. But the inevitability of which General Chi speaks may well be compounded by the strategic calculus of the US itself.

\section{The US strategic paradigm}

The United States has no strategic icon quite like Sun Tze. Consequently, there is no 'great tradition' on which US planners can rely. The strategic policies of the US have, over time, been influenced by a variety of thinkers, mostly European. It was George Washington's genius that saw the fledgling US military forces, during the War of Independence, pursue strategies with which Mao Tse-tung would have been familiar: the techniques of revolutionary political discourse supported by the tactics of a popularly supported insurgency. Thomas Jefferson, for his part, was more influenced by the ideas that created the French Revolution, and fascinated by the leverage that France provided the newly independent United States in its dealings with Great Britain. But while he was an able Secretary of State, Jefferson was no strategist.

While the northern and southern military academies paid some attention to Henri, baron de Jomini, it was not until the decades following the Civil War that 
American military planners began to give more serious attention to the development of strategy. In many respects, strategy followed on the coat-tails of the growing international influence enjoyed by the United States as its economy boomed. The Civil War, of course, gave birth to a number of outstanding land warfare theorists, especially at the tactical and operational levels of war. Perhaps the only true strategist of this period was Alfred Thayer Mahan, whose essay 'The Influence of Sea Power upon History' marked the beginning of the more global approach to the deployment and employment of naval power for which the US has become such a forceful exponent. Indeed, Mahan was probably the founder of the identifiably American school of strategy.

During the later part of the nineteenth century, the US military academies discovered Clausewitz. While Clausewitz was widely read, there is not much evidence that the underlying principles of $O n W a r$ were widely understood, at least by US army commanders. The retreat into isolationism that marked the decades immediately following World War I was hardly consistent with a view of armed force as an instrument of state policy. But the experiences of World War II, and the emergence of the United States not only as the principal architect, but also the principal beneficiary, of victory served to lend real impetus to the development of a characteristically 'American' school of strategic thinking.

Writers and thinkers such as Herman Kahn, Edward Luttwak and Henry Kissinger have left an indelible mark on the history of US strategic thinking. More importantly, perhaps, they have left their mark on US public policy, and it is in the official documents of the successive US administrations that one finds the clearest expression of US defence strategies and the paradigm that underlies them.

Although Secretary of Defense Donald Rumsfeld has advised Congress that the forthcoming Quadrennial Defense Review will differ from that of the Clinton administration in important respects, there has in fact been a remarkable consistency in US strategic policy -and its formulation-through the Reagan, Bush and Clinton administrations. The 1997 Quadrennial Defense Review, for instance, begins its chapter on defence strategy with the following sentiments.

Since the founding of the Republic, the United States has embraced several fundamental and enduring goals as a nation: to maintain the sovereignty, political freedom, and independence of the United States, with its values, institutions, and territory intact; to protect the lives and personal safety of Americans, both at home and abroad; and to provide for the well-being and prosperity of the nation and its people.

Achieving these basic goals in an increasingly interdependent world requires fostering an international environment in which critical regions are stable, at peace, and free from domination by hostile powers; the global economy and free trade are growing; democratic norms and respect for human rights are widely accepted... The United States seeks to play a leadership role in the international community, working closely and cooperatively with nations 
that share our values and goals, and influencing those that can affect US national well-being.

The Quadrennial Defense Review espouses a universalist and value-adding approach to strategy that echoes the modern US business approach to economic development: that economic growth can lead to benefits for all, rather than just for the dominant economic actors. It elaborates on several themes that were set out in President Clinton's February 1996 statement A National Security Strategy of Security and Enlargement, in which Clinton dealt with the political, economic and military elements that combine to establish an achievable national strategy. After noting the range of threats that continue to characterize the global security environment, President Clinton went on to say:

\begin{abstract}
We have unprecedented opportunities to make our nation safer and more prosperous...We now have a truly global economy linked by an instantaneous communications network...The community of democratic nations is growing, enhancing the prospects for political stability, peaceful conflict resolution and greater dignity and hope for the people of the world. The international community is beginning to act together to address pressing global environmental needs. Never has American leadership been more essential.
\end{abstract}

In a clear reflection of the 'net value-adding' concept of strategy, Clinton continued:

Our extraordinary diplomatic leverage to reshape existing security and economic structures and create new ones ultimately relies upon American power... But military force remains an indispensable element of our nation's power...The United States recognizes that we have a special responsibility that goes along with being a great power and, at times, our global interests and ideals lead us to oppose those who would endanger the survival or wellbeing of their peaceful neighbours.

\title{
'Dubya' says
}

To this point, President George W. Bush has not perhaps been the most eloquent of US presidents in articulating the strategic objectives of his administration. Yet the statements of his key advisors, and his own speeches, display a remarkable consistency with the themes elaborated during the previous two decades or so. On 1 May 2001, for instance, President Bush, speaking on the issue of deterrence against nuclear proliferation at the National Defense University, Fort McNair, said:

Today's world requires a new policy, a broad strategy of active nonproliferation, counterproliferation and defenses. We must work together with other like-minded nations to deny weapons of terror from those seeking to acquire them. We must work with allies and friends who wish to join with us to defend against the harm they can inflict... Deterrence can no longer be based solely on the threat of nuclear retaliation. Defenses can strengthen deterrence by reducing the incentive for proliferation. 
The issue here, of course, is less the ideas of non-proliferation and counterproliferation than partnership and the creation of incentives for achieving strategic outcomes.

It would, of course, be naive to suggest that the defence posture of the US is based on anything other than fighting and winning. That is an inevitable part of strategy. But US strategy also comprehends the utility of armed force as part of the array of state-controlled forces that deliver strategic outcomes that secure security and prosperity in the broadest strategic environment. Does that mean that the US is dedicated to 'humanitarian intervention' and the 'defence of democracy' wherever and whenever human beings are under duress or democratic institutions are attacked by external forces? No. But it does mean that, when the US finds that its longer-term interests and those of its partners are at stake, it will dedicate its military resources to the delivery of outcomes that not only accrue to its own benefit, but to the benefit of other nations as well. This is the strategy of selfinterested altruism that underpins the 'win-win' philosophy of modern commerce.

\section{The clash of the titans}

For a host of reasons - political, economic, social, cultural-m-the Chinese and US approaches to strategy not only fail to complement each other but they also set the foundations of basic misunderstanding and miscalculation. The underlying philosophies informing China's strategic calculus, on the one hand, and the strategic calculus of the US on the other are at cross purposes. China fundamentally pursues a 'zero-sum game' approach, where advance for one side is predicated upon retreat for the other, where victory for one side means defeat for the other, where a 'win' for one side means a 'loss' for the other. The United States has a quite different approach. Fundamental to US strategy is the idea that "victory' does not necessarily require the destruction of an opponent, but rather the acceptance of an outcome that effectively removes the uncertainties that cause armed conflict in the first place. For the United States, the driving concept is "net value-adding', where both sides are able to claim a 'win', albeit in somewhat different ways.

These two different concepts, 'zero-sum game' and 'net value-adding' serve to describe the fundamental forces that drive the tectonic plates of Chinese and US strategy.

\section{Examples of strategic non-congruence}

The last half of the twentieth century is replete with examples of the consequences of strategic non congruence. The USS Pueblo incident is, perhaps, the most poignant instance, though the Cuban missile crisis provides an instructive example of major powers on a collision course. In recent times, however, the continued standoff between China and the US over the future of Taiwan and the EP-3E incident in April 2001 provide stark examples of the miscalculations that are 
possible when the major protagonists are unable to engage on the same strategic premises.

Taiwan is, of course, the touchstone of China-US relations. Libraries have been written on the matter, and it is not the purpose of this chapter to revisit the issue. But it worthwhile noting that, because of their fundamentally different strategic paradigms, China and the United States have fundamentally different approaches to the issue-as does Taiwan. Put most simply, the issue boils down to this:

- China does not believe that the US would put itself at any serious strategic (and here one may assume nuclear) risk for Taiwan;

- the US wishes to maintain the maximum ambiguity conceming its strategic intentions should China seek to resolve the Taiwan issue militarily; and

- Taiwan, for its own purposes, choses to believe that the US would put itself at risk to protect Taiwan from forcible reintegration with China.

The result of this strategic trilemma is, of course, one of the most fascinating strategic problems presently confronting the planners of both China and the US.

Similarly, much has been written about the EP-3E incident that began on 1 April 2001, when a USN reconnaissance aircraft collided with a Chinese Air Force F-8 some 70 nautical miles off the coast of China. The issue here is not the circumstances of US electronic warfare surveillance, or the flying abilities of PLA(AF) fighter pilots. Nor is the issue really about the rights or wrongs of surveillance or interception. The issue is the astonishing mishandling of the incident by China.

Now, it is germane that Jiang Zemin was in South America, and that the available communications bandwidth between Beijing and the travelling President was so narrow. Distance and poor communications doubtless combined to ensure that the handling of the issue was as inept as it turned out to be. But the fundamental problem for China was its total misreading of both the circumstances that led to the incident and the likely attitude of the US. China wanted to exploit the event in much the same way as the former Soviet Union wanted to exploit the Gary Powers U-2 incident. But China was in a 'no-win' situation. The more incompetently it managed the disabled aircraft's position on the tarmac of a PLA $(A F)$ airbase on Hainan and the inability of the USN crew to do very much at all about its own plight, the greater the relative disadvantage it put itself into with respect to the United States. Simply, it turned an event of its own causation (albeit mistakenly so) into a major setback for its own strategic position. And it did so because it saw its own 'win' as necessitating a US 'loss'.

Major and fundamental differences in the way in which China and the United States even perceive the world of strategy will continue to be intrinsic to miscalculation and confrontation. 


\section{Is armed conflict inevitable?}

Notwithstanding the sentiments ascribed to China's Defence Minister, Chi Haotian, divergent strategic paradigms do not necessitate war. While war between China and the US may conceivably occur at some time in the future, Taiwan is probably unlikely to be the precipitating factor. But if the non-congruence in the basic strategic perceptions of China and the US does not lead inevitably to war, it does most certainly lead to a significant increase in the risk of misunderstanding, disagreement and miscalculation between the two sides which, in turn, could lead to armed confrontation. There are no certainties in peace, and even fewer in war. But self-interest, and a clear appreciation of the consequences of engagement, will continue to deter both China and the US from stumbling into armed conflict. As the EP-3E incident so eloquently demonstrated, even the stupidity of one side will not necessarily provoke the other into a military engagement.

But ambiguity and the inability truly to understand the basic strategic calculus of the other side combine to make the orderly conduct of a strategic relationship between China and the US almost impossible. In some respects, neither side wants to admit that the other might have a legitimate claim to a measure of strategic leadership. Both sides wish to see the other as strategically inferior. But the fact that, for China, strategic inferiority is absolute whereas, for the United States, it is relative, determines both the unsatisfactory nature of the strategic dialogue and the dangerous nature of the strategic outcome. Strategic convergence is impossible and effective engagement is only superficially achievable.

In judging whether the tectonic plates on which Chinese and US strategy move must inevitably collide, it may be worth taking a little comfort from Francis Fukuyama's optimistic analysis, The End of History and the Last Man. Fukuyama postulates the eventual triumph of democratic (capitalistic) liberalism over other forms of government, principally because those forms impose greater constraints on individual freedom. Commenting on the pressure that the growing tide of democratic practice puts on China, he says:

\footnotetext{
China after Tienanmen Square is far from having achieved democracy, but since the beginning of the economic reform its foreign policy has become, so to speak; increasingly bourgeois. The current leadership of China seems to understand that it cannot turn the clock back on economic reform, and that China will have to remain open to the international economy. This has discouraged any return to a Maoist foreign policy, despite the attempt to revive aspects of Maoism domestically (Fukuyama 1992, 277).
}

Does this mean that the fundamental structures of China's historical strategy will adapt quickly to new forms of liberal democratic expression, and that it will join the characteristically 'peaceful' democracies? 'If democracies do not fight one another, then a steadily expanding post-historical world will be more peaceful and prosperous', Fukuyama $(1992,280)$ notes. But liberalism has triumphed only in the ideal world: it remains fragmentary in the 'material' world, the world of (lowercase) history with its humdrum day-to-day events. In the 'post-historical' world, 
Fukuyama reminds us, "the nation-state will continue to be the chief locus of political identification' (277). So, the wait for a democratic China could be a long one, and the Chinese state will remain the chief rallying point of the Chinese people. Miscalculation and misadventure, therefore, will continue to dog the strategic relationship between the world's most populous nation and the world's richest one.

\section{What are Australia's options?}

As with all minor players on the international stage, Australia does have options. It could choose not to be on stage at all, to vacate any position of responsibility for one of irrelevance. It could choose to be a neutral bystander, with no input into the resolution of the problem and even less effect on the outcome. It could choose to follow its short-term economic interests, maintain its economic links with China, and maintain the greatest possible measure of separation from the US. It could choose to support the United States totally and unthinkingly, without any consideration being given to its long-term interests in North Asia. Or it could choose to consider the fundamental dynamics of the strategic relationship between China and the United States, appreciate the fundamental convergences between its own strategic paradigm and values structures and those of the US, and seek to participate in a strategic result that confers benefits to all parties.

For its part, China would most certainly call on Australia to distance itself from the United States, if only to maintain a reasonable chance of prosecuting a mutually beneficial economic relationship over the longer term. China would seek to have Australia play a 'balancing role', whereby Australia created a measure of strategic separation from the US in order to maximize its stake in subsequent Chinese reconstruction.

For its part, the United States would want to see Australia fully committed to an allied cause. It would expect that the strategic intelligence relationship would proceed unimpeded, and would also expect that Australia would make key strategic assets available to the United States in the prosecution of its interests. In all likelihood, the US would expect support that was significant, though not necessarily substantial. And it would most certainly expect Australia to be aligned with both its strategic goals and the preferred means of realizing those goals.

And what of Australia? For its part, Australia would probably seek to steer a middle course diplomatically, while admitting the inevitability of its alliance obligations. But to resolve this tension by remaining neutral with respect to both the protagonists and the outcome would represent the most dangerous course. For it would be an abnegation of choice. Moreover, it would mistake the techniques of diplomacy for the outcomes of strategy.

And herein lies Australia's dilemma: the outcomes of diplomacy would probably not secure the strategic advantages Australia most wanted. But the very fact that Australia would need to confront the difference between a 'rock' and a 'hard place' would, of itself, generate a new maturity in Australia's approach to 
managing its own strategic future in Asia. For, fundamentally, strategy deals with the ultimate things - survival, and the role of armed force in securing that. While its value structures remain fully aligned with those of its liberal democratic friends and allies, Australia will need to join with them in the defence of those values-as it did during the two world wars of the twentieth century.

Australia cannot afford to be indifferent to the fundamental strategic divergence between China and the United States. While an active and constructive diplomacy will continue to engage with China, and continue to work towards minimizing the consequences of strategic differences between China and the United States, Australia will necessarily maintain the strategic relationship it enjoys with the United States - if only because, in a fundamental sense, its strategic interests are convergent with US interests. And its strategic interests are not convergent with those of China. Australia's strategic option is clear.

\section{References}

Chi, Hao-tian. 1999. Conference of the Military Command College [sic], December, sourced from Xinhua News Agency, Beijing, 11 Jan 2000, reported in the BBC Summary of World Broadcasts, 13 Jan 2000.

Clausewitz, Carl von. 1984. On War, edited and translated by Michael Howard and Peter Paret, Princeton: Princeton University Press.

Downer, Alexander. 1999. Department of Foreign Affairs and Trade transcript, 31 August.

Fukuyama, Francis. 1992. The End of History and the Last Man. New York: The Free Press.

Harding, Harry. 1986. (Dean of the Elliott School of International Affairs, George Washington University), conversation with the author, September.

Mao Tse-tung. 1936. 'Problems of Strategy in China's Revolutionary War'. In Selected Works of Mao Tse-tung, vol. 1.

Mao Tse-tung. 1949. 'Address to the Preparatory Meeting of the New Political Consultative Conference'. In Selected Works of Mao Tse-tung, vol. 4. Peking: Foreign Languages Press.

Mao Tse-tung. 1964. 'Statement supporting the people of the Congo against US aggression (28 November 1964)', People of the World, Unite and Defeat the US Aggressors and All Their Lackeys, 2nd ed. 